\title{
Mechanisms of obesity-associated insulin resistance: many choices on the menu
}

\author{
Mohammed Qatanani and Mitchell A. Lazar ${ }^{1}$ \\ Division of Endocrinology, Diabetes, and Metabolism, and The Institute for Diabetes, Obesity, and Metabolism University \\ of Pennsylvania School of Medicine, Philadelphia, Pennsylvania 19104 USA
}

\begin{abstract}
Obesity-associated insulin resistance is a major risk factor for type 2 diabetes and cardiovascular disease. In the past decade, a large number of endocrine, inflammatory, neural, and cell-intrinsic pathways have been shown to be dysregulated in obesity. Although it is possible that one of these factors plays a dominant role, many of these factors are interdependent, and it is likely that their dynamic interplay underlies the pathophysiology of insulin resistance. Understanding the biology of these systems will inform the search for interventions that specifically prevent or treat insulin resistance and its associated pathologies.
\end{abstract}

The number of obese individuals worldwide has reached 2.1 billion, leading to an explosion of obesity-related health problems associated with increased morbidity and mortality (Li et al. 2005; Olshansky 2005). Obese individuals develop resistance to the cellular actions of insulin, characterized by an impaired ability of insulin to inhibit glucose output from the liver and to promote glucose uptake in fat and muscle (Saltiel and Kahn 2001; Hribal et al. 2002). Insulin resistance is a key etiological factor for type 2 diabetes mellitus (T2DM), which has reached epidemic proportions: In the United States, $\sim 6 \%$ of the current adult population is diagnosed with this disease. An additional 41 million people are prediabetic, with a constellation of insulin resistance, hypertension, and dyslipidemia that puts them at increased risk for cardiovascular morbidity and mortality (Zimmet et al. 2001; American Diabetes Association diabetes statistics at http://www.diabetes.org/diabetes-statistics/prevalence. jsp). Lifestyle changes, while desirable, have proven difficult to achieve. Thus, a better understanding of the molecular mechanisms underlying insulin resistance will be required to combat the epidemics of T2DM and cardiovascular disease that are fueled by obesity-associated insulin resistance. The association between obesity and insulin resistance is likely a cause-and-effect relationship since hu-

[Keywords: Adipocyte; adipokines; diabetes; insulin resistance; obesity; signaling]

${ }^{1}$ Corresponding author.

E-MAIL lazar@mail.med.upenn.edu; FAX (215) 898-5408.

Article is online at http://www.genesdev.org/cgi/doi/10.1101/gad.1550907. man and animal studies indicate that weight loss/gain correlates closely with increasing/decreasing insulin sensitivity, respectively (Sims et al. 1973; Freidenberg et al. 1988; Bak et al. 1992). In this review, we explore current ideas of how increased adipose mass predisposes to systemic insulin resistance, focusing on dysregulation of interconnected endocrine, inflammatory, neural, and cell-autonomous pathways.

\section{Endocrine mechanisms}

\section{Fatty acids (FAs)}

It has long been recognized that plasma FA concentrations are commonly elevated in obese individuals, mainly due to increased FA release associated with the expansion in fat mass (Gordon 1964; Bjorntorp et al. 1969; Jensen et al. 1989). Classically, FAs secreted from adipocytes have been considered to serve entirely as energy sources for other tissues of the body. The notion that these FAs function as endocrine factors that regulate metabolic function in target tissues was first suggested $>40$ years ago, when Randle et al. (1963) hypothesized that obesity-associated insulin resistance could be explained by competition between these increased circulating FAs and glucose for oxidative metabolism in insulin-responsive cells. More recently, glucose uptake rather than intracellular glucose metabolism has been implicated as the rate-limiting step for FA-induced insulin resistance (Shulman 2000). In this model, FAs and potentially several metabolites including acyl-CoAs, ceramides, and diacyglycerol serve as signaling molecules that activate protein kinases such as Protein Kinase C (PKC), Jun kinase (JNK), and the inhibitor of nuclear factor- $\kappa \mathrm{B}(\mathrm{NF}-\kappa \mathrm{B})$ kinase- $\beta$ (IKK $\beta)$. These kinases can then impair insulin signaling by increasing the inhibitory serine phosphorylation of insulin receptor substrates (IRS), the key mediators of insulin receptor signaling (Fig. 1A; for review, see Petersen and Shulman 2006).

\section{Adipokines}

Adipocytes also secrete metabolically active proteins (Fig. 1B; for review, see Rajala and Scherer 2003; Kershaw 


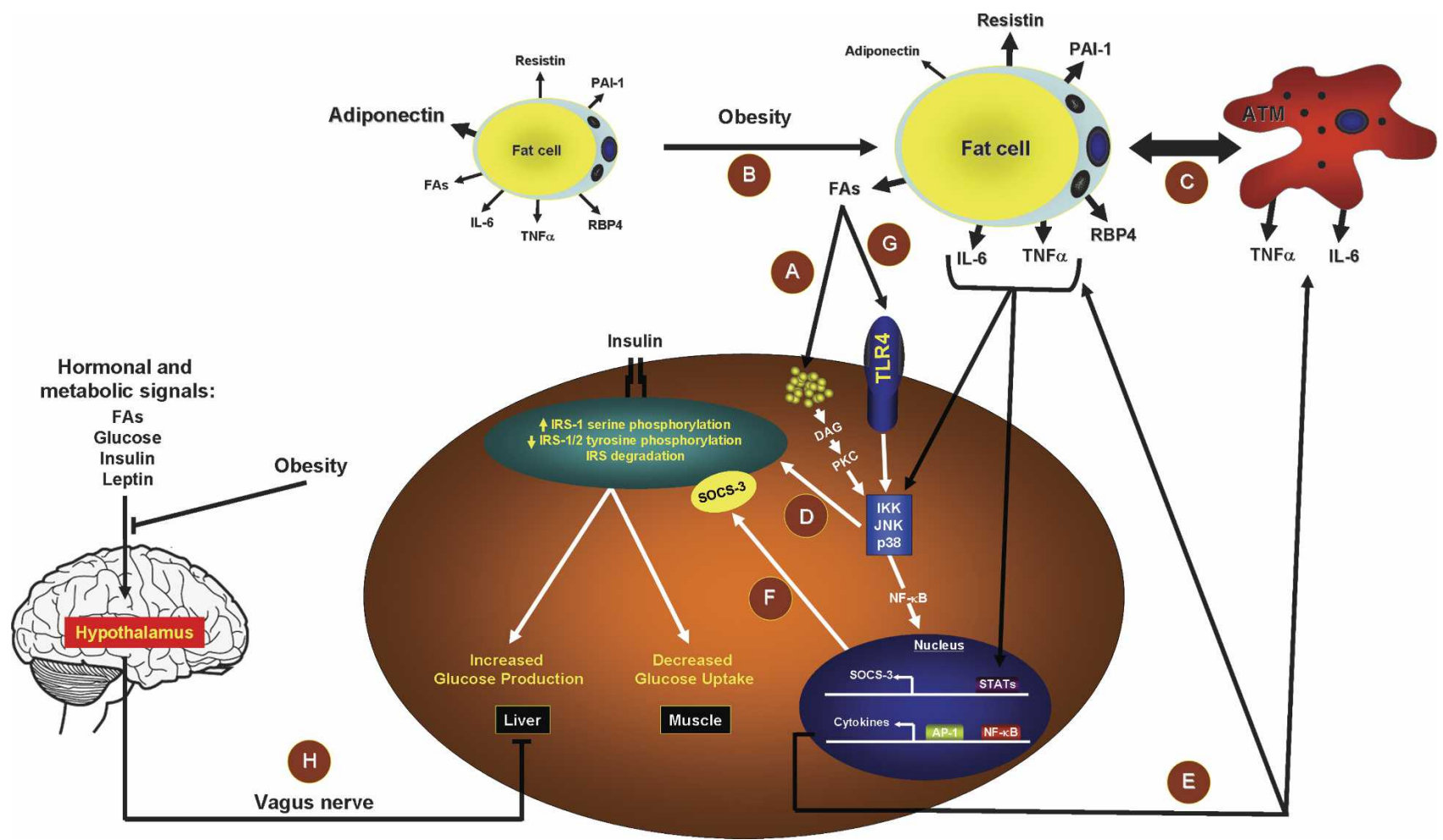

Figure 1. Endocrine, inflammatory, and neuronal pathways link obesity to insulin resistance. $(A)$ The obesity-associated increase in FAs can trigger insulin resistance through intracellular metabolites that activate PKC, leading to the activation of serine/threonine kinases that inhibit insulin signaling. $(B)$ Obesity-associated changes in secretion of adipokines that modulate insulin signaling. $(C)$ Obesity-associated inflammatory factors. Obesity is characterized by an increase in the accumulation of ATMs, which increase the adipose tissue production of inflammatory cytokines that inhibit insulin signaling. $(D)$ Endocrine and inflammatory mediators converging on serine/threonine kinases that inhibit insulin signaling. (E) Obesity-associated activation of NF- $\mathrm{B}$ heightens inflammatory responses that exacerbate insulin resistance. $(F)$ SOCS family proteins, induced by adipokines, induce insulin resistance either by interfering with IRS-1 and IRS-2 tyrosine phosphorylation or by targeting IRS-1 and IRS-2 for proteosomal degradation. (G) FAs also trigger insulin resistance by direct activation of TLR4 and the innate immune response. $(H)$ Obesity-related alteration in the central response to hormonal and nutrient signals alters peripheral insulin sensitivity.

and Flier 2004). Leptin is an adipocyte-secreted hormone whose absence leads to dramatic metabolic derangements (Ingalls et al. 1950). The discovery of leptin by Friedman and colleagues in 1994 (Zhang et al. 1994) ushered in an era of receptivity to the notion that adipose tissue is an endocrine organ, and that increased adipose mass in obesity could lead to pathological changes in adipocyte hormones (adipokines) that regulate insulin sensitivity.

Adiponectin was independently characterized in 1995 and 1996 by four groups using different methods (Scherer et al. 1995; Choi-Miura et al. 1996; Hu et al. 1996; Maeda et al. 1996). Adiponectin is structurally related to complement $1 \mathrm{q}$, is specifically expressed in differentiated adipocytes, and circulates at high levels in the bloodstream (Chandran et al. 2003). Adiponectin levels are low in obesity, and administration of adiponectin improves insulin resistance in animal models (Berg et al. 2001; Kubota et al. 2002; Diez and Iglesias 2003). Adiponectin-deficient mice develop premature diet-induced glucose intolerance and insulin resistance, and increased serum FAs (Kubota et al. 2002; Maeda et al. 2002). In contrast, transgenic overexpression of adiponectin in mice leads to improved insulin sensitivity, glucose tolerance, and lower serum FAs (Maeda et al. 2002; Combs et al. 2004). Several mechanisms for adiponectin's metabolic effects have been described (Berg et al. 2001; Yamauchi et al. 2002). In the liver, adiponectin enhances insulin sensitivity, decreases influx of FAs, increases FA oxidation, and reduces hepatic glucose output (Combs et al. 2004). In muscle, adiponectin stimulates glucose use and FA oxidation probably via activation of the cellular fuel sensor, AMP-activated protein kinase (AMPK) (Fruebis et al. 2001; Tomas et al. 2002; Yamauchi et al. 2002).

Resistin was identified in 2001 as an adipocyte-specific secreted protein whose expression is down-regulated by anti-diabetic drugs targeting the nuclear receptor peroxisome proliferator-activated receptor $\gamma(\operatorname{PPAR} \gamma)$ (Holcomb et al. 2000; Kim et al. 2001; Steppan et al. 2001). Serum resistin is elevated in rodent obesity, and infusion or sustained expression of resistin produces insulin resistance (Rajala et al. 2003; Rangwala et al. 2004; Satoh et al. 2004; Qi et al. 2006). Conversely, mice lacking resistin have improved glucose homeostasis (Banerjee et al. 2004). This effect is mediated at least in part via increased activity of AMPK and decreased expression of 
gluconeogenic enzymes in the liver. Moreover, resistin has been shown to induce the expression of Suppressor of Cytokine Signaling-3 (SOCS-3), a well-known negative regulator of insulin signaling (Emanuelli et al. 2001), both in vitro and in vivo (Steppan et al. 2005). The role of resistin in humans is less certain. While mouse resistin is exclusively expressed in white adipose tissue, human resistin is mainly expressed in circulating mononuclear cells (Savage et al. 2001; Steppan et al. 2001; Patel et al. 2003). Some studies show increased resistin expression and serum levels in association with obesity and insulin resistance (Vidal-Puig and O'Rahilly 2001; C.L. McTernan et al. 2002; P.G. McTernan et al. 2002; Wang et al. 2002; Smith et al. 2003; Osawa et al. 2004, 2005). However, other studies failed to show such an association (Janke et al. 2002; Kielstein et al. 2003; Patel et al. 2003). Intriguingly, recent studies in humans show a consistent association between resistin and inflammation (Lehrke et al. 2004; Reilly et al. 2005; Pang and Le 2006; Senolt et al. 2006).

Several other adipokines are also associated with inflammation. Plasminogen activator inhibitor-1 (PAI-1) is a member of the serine protease inhibitor family and is the primary inhibitor of fibrinolysis by inactivating tissue-type plasminogen activator. PAI-1 is expressed by adipocytes as well as stromal vascular cells in adipose depots (Fain et al. 2004). Plasma PAI-1 levels are elevated in obesity and insulin resistance and predict future risk for T2DM (Mertens and Van Gaal 2002; Juhan-Vague et al. 2003). Mice with targeted deletion in PAI-1 have decreased weight gain on a high-fat diet, increased energy expenditure, improved glucose tolerance, and enhanced insulin sensitivity (Ma et al. 2004).

Interleukin-6 (IL-6) is a cytokine that is closely associated with obesity and insulin resistance (FernandezReal and Ricart 2003). Adipose tissue IL-6 expression accounts for $\sim 30 \%$ of systemic IL-6, and circulating IL-6 concentrations are positively correlated with obesity, impaired glucose tolerance, and insulin resistance (Bastard et al. 2002). Plasma IL-6 concentrations predict the development of T2DM (Vozarova et al. 2001), and peripheral administration of IL- 6 induces hyperlipidemia, hyperglycemia, and insulin resistance in rodents and humans (Stith and Luo 1994; Tsigos et al. 1997; Petersen et al. 2005). IL-6 impairs insulin signaling in part by downregulation of IRS and up-regulation of SOCS-3 (Rieusset et al. 2004). Assessing a role for IL-6 in murine models has been problematic because IL-6 knockout mice are paradoxically insulin resistant (Wallenius et al. 2002).

Tumor necrosis factor $\alpha$ (TNF $\alpha)$ is a cytokine initially described as an endotoxin-induced factor (Carswell et al. 1975). TNF $\alpha$ was the first cytokine to be implicated in the pathogenesis of obesity and insulin resistance (Hotamisligil et al. 1993). Adipose tissue expression of TNF $\alpha$ is increased in obese rodents and humans and positively correlated with adiposity and insulin resistance (Hotamisligil et al. 1993; Fernandez-Real and Ricart 2003; Hotamisligil 2003; Ruan and Lodish 2003). Recent studies suggest that macrophages are the major source of $\mathrm{TNF} \alpha$ in adipose tissue (Weisberg et al. 2003). Chronic exposure to TNF $\alpha$ induces insulin resistance both in vitro and in vivo (Ryden et al. 2002; Ruan and Lodish 2003). Treatment with neutralizing soluble TNF $\alpha$ receptors improves insulin sensitivity in rodent obesity (Hotamisligil et al. 1993; Cheung et al. 1998). Targeted gene deletion of $T N F \alpha$ or its receptors significantly improves insulin sensitivity and circulating FAs in rodent obesity (Uysal et al. 1997). Several potential mechanisms for TNF $\alpha$ 's metabolic effects have been described, including the activation of serine kinases such as JNK and p38 mitogen-activated protein kinase (MAPK) that increase serine phosphorylation of IRS-1 and IRS-2, making them poor substrates for insulin receptor-activating kinases and increasing their degradation (Hotamisligil et al. 1996; Stephens et al. 1997). In humans, circulating TNF $\alpha$ levels are increased in obese nondiabetic and T2DM individuals, but the correlation between insulin resistance and plasma TNF $\alpha$ levels is relatively weak (Hotamisligil et al. 1995; Nilsson et al. 1998; Zinman et al. 1999; Miyazaki et al. 2003).

The most recent adipokine to emerge as a contributor to obesity-induced insulin resistance is retinol-binding protein 4 (RBP4). RBP4 was identified as an adipokine whose expression is increased in the adipose tissue of mice rendered insulin resistant by adipose-specific inactivation of the glucose transporter GLUT4 (Yang et al. 2005). RBP4 is highly expressed in liver as well as adipose tissue, and its circulating levels have been shown to correlate with obesity and insulin resistance in rodents (Yang et al. 2005). In humans, RBP4 levels have been shown to be elevated in several groups of insulin-resistant subjects (Graham et al. 2006; Gavi et al. 2007), but not all studies have shown such differences (Janke et al. 2006; Takashima et al. 2006). It has been suggested that increased serum RBP4 levels might contribute to insulin resistance by impairing insulin-stimulated glucose uptake in muscles and elevating hepatic glucose production, although the mechanism is not fully clear (Yang et al. 2005).

\section{Other adipocyte factors}

Cortisol is another endocrine factor produced by adipose tissue. Elevated glucocorticoid levels cause insulin resistance and T2DM (Seckl et al. 2004), primarily by opposing the anti-gluconeogenic effects of insulin in the liver. Circulating glucocorticoid levels are near normal in obesity (Hautanen et al. 1997). However, adipose tissue contains $11 \beta$-hydroxysteroid dehydrogenase type 1 (11ßHSD1), which converts the inactive metabolite, cortisone, to cortisol. Transgenic overexpression of $11 \beta$ HSD1 selectively in mouse adipose tissue produces a syndrome of visceral obesity, insulin resistance, and diabetes (Masuzaki et al. 2001), suggesting that increases in endogenous $11 \beta$-HSD1 that have been observed in adipose tissue of obese humans and rodents (Livingstone et al. 2000; Rask et al. 2001; Paulmyer-Lacroix et al. 2002) contribute to obesity-associated insulin resistance, in part due to increased delivery of glucocorticoids to the liver via the portal vein. Indeed, liver-specific antago- 
nism of glucocorticoid action reduces hepatic glucose output and improves glucose control in animal models of obesity-associated insulin resistance (Jacobson et al. 2005).

In addition to states of glucocorticoid excess, visceral adiposity is characteristic of people with an "appleshaped" fat distribution, who appear to have a greater risk of developing insulin resistance than individuals with more peripheral "pear-shaped" fat distribution (Kabir et al. 2005). The "portal theory" suggests that insulin resistance in the liver arises from visceral fat drainage directly into the liver via the portal vein (Bergman et al. 2007). The increased delivery of FA and cortisol, as well as adipokines (Bujalska et al. 1997; Fontana et al. 2007), could promote hepatic insulin resistance by the mechanisms discussed earlier. Other molecular differences between visceral and peripheral fat may also contribute to insulin resistance associated with visceral adiposity (Gesta et al. 2006; Fontana et al. 2007).

\section{Inflammatory mechanisms}

Systemic chronic inflammation has been proposed to have an important role in the pathogenesis of obesityrelated insulin resistance (Hotamisligil et al. 1995; Weisberg et al. 2003; Xu et al. 2003; Wellen and Hotamisligil 2005). Unequivocal experimental, epidemiological, and clinical evidence produced during the past decade causally links inflammation to the development of insulin resistance and T2DM (Dandona et al. 2004; Shoelson et al. 2006). It has been shown that biomarkers of inflammation, such as TNF $\alpha$, IL-6, and C-reactive protein $(\mathrm{CRP})$, are present at increased concentrations in individuals who are insulin resistant and obese, and these biomarkers predict the development of T2DM. Activation of inflammatory pathways in hepatocytes is sufficient to cause both local (Arkan et al. 2005) as well as systemic insulin resistance (Cai et al. 2005). Furthermore, obesity is characterized by macrophage accumulation in white adipose tissue, which has added another dimension to our understanding of the development of adipose tissue inflammation in obesity (Weisberg et al. 2003; Xu et al. 2003). Adipose tissue macrophages (ATMs) are likely to contribute to the production of several of the adipokines discussed earlier. A causative role of ATMs in obesity-associated insulin resistance has been recently supported by studies showing that inhibition of macrophage recruitment in obesity ameliorates the insulin resistance seen in animal models (Fig. 1C; Kanda et al. 2006; Weisberg et al. 2006; Lumeng et al. 2007).

Several signaling pathways link the endocrine and inflammatory mechanisms of insulin resistance (Fig. 1D). An important kinase likely to mediate the cross-talk between inflammatory and metabolic signaling is JUN Nterminal kinase1 (JNK1), a serine/threonine protein kinase that is activated by many inflammatory stimuli including TNF $\alpha$ (Hirosumi et al. 2002). In both genetic and dietary animal models of obesity, JNK1 activity is increased in the liver, muscle, and adipose tissue, and loss of JNK1 prevents insulin resistance (Hirosumi et al. 2002). Modulation of hepatic JNK1 in adult animals also produces systemic effects on glucose metabolism, which underscores the importance of this pathway in the liver (Nakatani et al. 2004). Activation of JNK1 leads to serine phosphorylation of IRS-1 that impairs insulin action (Aguirre et al. 2000; Gao et al. 2004). In addition, IKK $\beta$ is a mediator of TNF-induced insulin resistance (Yuan et al. 2001). Activation of NF-кB caused by continuous lowlevel expression of $I K K \beta$ in hepatocytes from a transgenic mouse model leads to moderate systemic insulin resistance (Cai et al. 2005). Moreover, inhibition of IKK $\beta$ in human diabetics by high-dose aspirin treatment also improves insulin signaling (Yin et al. 1998; Hundal et al. 2002). IKK $\beta$ can impact insulin signaling both by directly phosphorylating IRS-1 on the inhibitory serine residues (Yin et al. 1998; Gao et al. 2002) and by phosphorylating

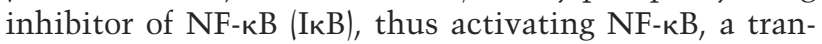
scription factor that, among other targets, stimulates production of multiple inflammatory mediators including TNF $\alpha$ and IL-6 (Shoelson et al. 2003). This might trigger a vicious loop of heightened inflammatory responses that feed into the negative regulation of insulin signaling discussed earlier (Fig. 1E).

Another class of inflammatory mediators contributing to obesity-induced insulin resistance are SOCS proteins, which constitute a negative feedback pathway in cytokine signaling (Fig. 1F). At least three members of the SOCS family (SOCS-1, SOCS-3, and SOCS-6) have been implicated in cytokine-mediated inhibition of insulin signaling (Emanuelli et al. 2001; Mooney et al. 2001; Rui et al. 2002), either by interfering with IRS-1 and IRS-2 tyrosine phosphorylation or by targeting IRS-1 and IRS-2 for proteosomal degradation (Rui et al. 2002; Ueki et al. 2004a). Interestingly, recent studies reported increases in SOCS-3 in obese rodents, and reduction in SOCS-3 expression results in resistance to high-fat-diet-induced obesity and insulin resistance (Howard et al. 2004; Shi et al. 2004; Ueki et al. 2004a). In contrast, overexpression of SOCS-1 and SOCS-3 in the liver causes systemic insulin resistance (Ueki et al. 2004b).

Finally, recent studies have provided more clues to the interrelationship between obesity, inflammation, stress, and insulin resistance (Matsuzawa et al. 2005; Shi et al. 2006; Suganami et al. 2007). Shi et al. (2006) showed that Toll-Like Receptor 4 (TLR4), which plays a critical role in innate immunity, is activated by FAs and that mice lacking TLR4 are substantially protected from the ability of systemic lipid infusion to induce insulin resistance (Fig. 1G). Moreover, Matsuzawa et al. (2005) showed that ASK1, a member of the MAPK kinase-kinase (MAP3K) family, specifically mediates a branch of TLR4 signaling through a reactive oxygen species (ROS)-dependent pathway. Given the ability of ASK1 to activate the JNK pathway (Tobiume et al. 2001), this finding may provide an additional link between innate immunity, cellular stress, and insulin resistance.

\section{Neural mechanisms}

A key role for the brain in glucose homeostasis was suggested more than a century ago (Bernard 1854). Recent 
evidence now indicates that the brain processes information from adiposity signals such as insulin and leptin, which circulate in proportion to body fat mass, and integrates this input with signals from nutrients such as FAs (Burcelin et al. 1999; Niswender et al. 2001; Obici et al. 2003; Seeley and Woods 2003; Pocai et al. 2006). In response, the brain sends signals to control feeding behavior and substrate metabolism in ways that promote homeostasis of both energy stores and fuel metabolism (Fig. 1H).

Both leptin and insulin play a role in the central control of peripheral glucose metabolism. The insulin resistance of lipodystrophic and leptin-deficient mice is ameliorated by central leptin administration at doses that are much lower than the systemic doses needed to achieve the same phenotype (Ebihara et al. 2001; Asilmaz et al. 2004; Pocai et al. 2005a). Moreover, inhibition of hypothalamic insulin receptor function results in hepatic insulin resistance and impaired inhibition of hepatic glucose output (Obici et al. 2002a,c). Peripheral and brain insulin receptors are both required for normal insulin action (Okamoto et al. 2004), although central administration of insulin alters glucose homeostasis in mice with reduced hepatic insulin receptors (Buettner et al. 2005). Intriguingly, leptin and insulin both induce the expression of SOCS-3, and sensitivity to both insulin and leptin is augmented in mice with reduced neuronal expression of SOCS-3 (Mori et al. 2004).

Obesity-associated nutrients such as FAs also have central effects on insulin action. Central infusion of oleic acid potently increases hepatic insulin sensitivity in rats (Obici et al. 2002b), and similar effects were noted after central infusion of an inhibitor of carnitine palmitoyltransferase-1 (CPT-1) (Obici et al. 2003), which increases hypothalamic fatty acyl-CoA by reducing FA oxidation. Central CPT-1 inhibition activates neurons in brain stem areas that control parasympathetic outflow and increased hepatic insulin sensitivity through a mechanism that involves activation of vagal efferent fibers that supply the liver (Pocai et al. 2005b).

The CNS is also critical to circadian rhythms, and mice lacking a key component of the molecular circadian clock in the hypothalamus (Clock mutants) develop a metabolic syndrome of hyperlipidemia, hepatic steatosis, and hyperglycemia (Turek et al. 2005). Misalignment of food intake with the expression levels of neuroactive peptides, such as leptin, could create metabolic imbalances that alter insulin sensitivity. This is supported by a recent human study that reported that workers with alternating shift work had a higher risk for developing diabetes compared with their day shift counterparts (Suwazono et al. 2006).

\section{Cell-intrinsic mechanisms}

Ectopic fat storage

Chronically, the increased circulating FAs and other lipids that occur in obesity lead to ectopic fat storage as triglycerides in muscle and liver (Fig. 2A). Ectopic lipid accumulation has been implicated in insulin resistance (Unger and Orci 2000; McGarry 2002), potentially due to triglyceride turnover and production of the FA-derived signaling molecules noted above, or to activation of deleterious intracellular pathways such as ROS, mitochondrial dysfunction, or endoplasmic reticulum (ER) stress as discussed below.

\section{Oxidative stress}

Systemic oxidative stress, defined as a persistent imbalance between the production of highly reactive molecular species (chiefly oxygen and nitrogen) and antioxidant defenses, correlates with fat accumulation in humans and mice (Fig. 2B; Halliwell 1995; Rosen et al. 2001; Evans et al. 2002). The hypothesis that oxidative stress is a causative factor in the development of insulin resistance has been supported by several studies that showed that reversal of the imbalance between ROS and antioxidants improves insulin resistance in mice and humans (Khamaisi et al. 1997; Jacob et al. 1999; Konrad et al. 1999; Maddux et al. 2001; Haber et al. 2003; Furukawa et al. 2004; Fridlyand and Philipson 2006; Houstis et al. 2006). Many of the human studies on the link between oxidative stress and insulin resistance focus on the generation of ROS by hyperglycemia in diabetic patients, implicating ROS as a consequence of diabetes-induced hyperglycemia and not a causative factor for insulin resistance (Evans et al. 2002, 2003). However, since insulin resistance is evident before the development of chronic (fasting) hyperglycemia, it is unlikely that insulin resistance at the prediabetic stage results from oxidative stress triggered by hyperglycemia per se (Reaven and Chen 1996; DeFronzo 2004). The increase in ROS in the prediabetic stage is more likely due to obesity-related elevations of FAs that cause oxidative stress due to increased mitochondrial uncoupling and $\beta$ oxidation, leading to the increased production of ROS (Wojtczak and Schonfeld 1993; Carlsson et al. 1999; Rao and Reddy 2001; Yamagishi et al. 2001). In healthy subjects, infusion of FAs causes increased oxidative stress and insulin resistance that is reversed by infusion with antioxidants such as glutathione (Paolisso et al. 1992, 1996; Paolisso and Giugliano 1996).

Several recent studies have addressed the molecular mechanisms by which oxidative stress might lead to insulin resistance. In vitro, ROS and oxidative stress lead to the activation of multiple serine/threonine kinase signaling cascades (Kyriakis and Avruch 1996; Evans et al. 2003). These activated kinases can act on a number of potential targets in the insulin signaling pathway, including the insulin receptor and the family of IRS proteins. For IRS-1 and IRS-2, an increase in serine phosphorylation decreases the extent of the activating tyrosine phosphorylation (Birnbaum 2001; Evans et al. 2003). The kinases that have been shown to be activated by oxidative stress include JNK, p38 MAPK, and IKK $\beta$ (Blair et al. 1999; Aguirre et al. 2000; Maddux et al. 2001; Yuan et al. 2001; Hirosumi et al. 2002). 


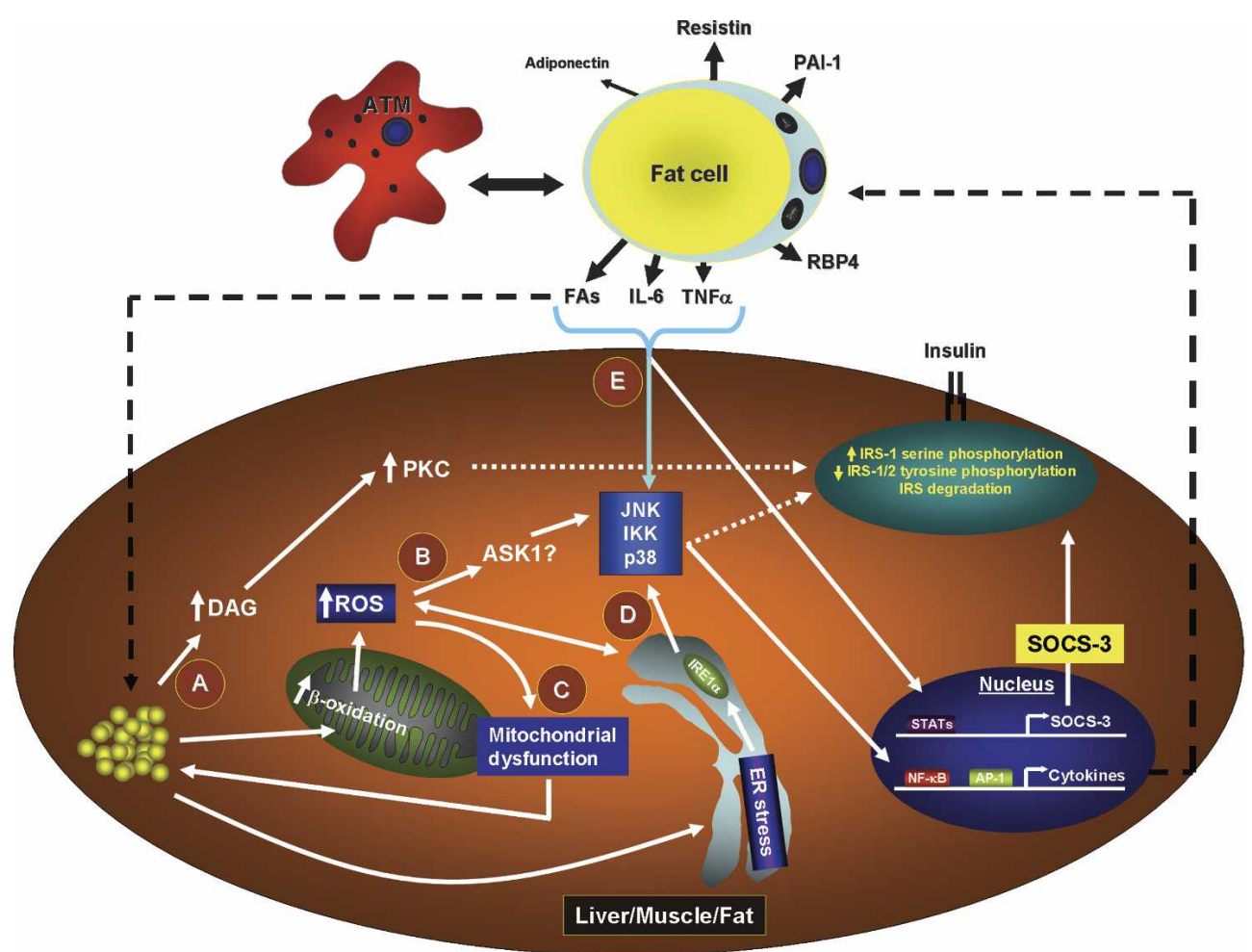

Figure 2. Obesity-associated intrinsic mediators of insulin resistance. Obesity leads to the dysregulation of several cell-intrinsic pathways that have a negative impact on insulin signaling. (A) Obesity leads to ectopic fat storage and an increase in FA metabolites that inhibit insulin signaling through activation of PKC in liver and muscle. $(B)$ Excess accumulation of lipids can trigger an increase in ROS generated by mitochondrial $\beta$ oxidation. Excess in ROS leads to activation of several serine/threoning kinases (JNK, IKK, and p38 MAPK) that inhibit insulin signaling either directly through IRS-1 or IRS-2 serine phosphorylation or indirectly through a series of transcriptional events mediated by NF-кB. $(C)$ Obesity is linked to mitochondrial dysfunction, which further exacerbates insulin resistance by increasing intracellular lipid accumulation. $(D)$ Obesity leads to the activation of cellular ER stress responses that suppress insulin signaling through the activation of JNK or through a potential increase in ROS production. $(E)$ Cell-intrinsic mechanisms of obesity-associated insulin resistance can be intensified by cell-extrinsic modulators such as endocrine and inflammatory signals.

\section{Mitochondrial dysfunction}

Insulin resistance and T2DM are associated with a decrease in mitochondrial function that contributes to the ectopic fat accumulation in muscle and fat (Petersen and Shulman 2006). Petersen et al. (2003) found that severe insulin resistance is associated with significantly higher levels of triglycerides in both muscle and liver in the elderly. These changes were accompanied by decreases in both mitochondrial oxidative activity and mitochondrial ATP synthesis, both indicative of a decrease in mitochondrial function. Other studies have revealed similar decreases in mitochondrial activity and increases in intramyocellular fat content in young insulin-resistant offspring of parents with T2DM, a group that has a strong tendency to develop diabetes later in life (Petersen et al. 2004). It was suggested that the insulin-resistant subjects accumulate more intramyocellular fat due to a decrease in the number of muscle mitochondria caused by a decrease in the expression of nuclear-encoded genes that regulate mitochondrial biogenesis, such as PPAR $\gamma$ coactivator $1 \alpha(P G C-1 \alpha)$ (Wu et al. 1999) and PGC-1 $\beta$ (St-Pierre et al. 2003). This idea is supported by microar- ray studies that show that PGC-1-responsive genes are down-regulated in obese Caucasians with impaired glucose tolerance and T2DM (Mootha et al. 2003), and PGC$1 \alpha$ and $P G C-1 \beta$ are themselves down-regulated in both obese diabetic and overweight nondiabetic MexicanAmericans (Patti et al. 2003). Finally, activation or induction of PGC-1 $\alpha$ has recently been shown to be associated with improved mitochondrial function as well as increased insulin sensitivity in both animals and humans (Lagouge et al. 2006; Mensink et al. 2007). These data support the idea that insulin resistance in humans might arise from defects in mitochondrial function, which in turn lead to increases in intracellular FA metabolites (fatty acyl-CoA and diacylglyerol) that disrupt insulin signaling in the muscle as well as the liver as discussed in the previous section.

The decrease in mitochondrial function associated with obesity and insulin resistance might seem paradoxical given that it is known that functional mitochondria are needed for an FA-induced increase in ROS (Evans et al. 2002). It is possible that an increase in ROS due to FA oxidation occurs early during the development of insulin resistance and prior to mitochondrial dysfunction. 
At a later stage, ROS might lead to a decrease in mitochondrial function that then leads to the accumulation of fat in the muscle and liver, exacerbating the insulin resistance phenotype via the mechanisms mentioned above (Fig. 2C).

\section{ER stress}

Another intracellular pathway implicated in insulin resistance is the ER stress response (Fig. 2D; Ozcan et al. 2004, 2006; Nakatani et al. 2005; Ozawa et al. 2005). In a seminal study, Ozcan et al. (2004) showed that obesity imposes a strain on the ER machinery, thereby triggering an ER stress response that activates JNK and impairs the insulin signaling pathway. Supporting a causal link between peripheral ER stress and insulin resistance, more recent studies have demonstrated protection against obesity-induced T2DM in mice by overexpression of ER chaperones, while knockdown of chaperones was diabetogenic (Nakatani et al. 2005; Ozawa et al. 2005). Furthermore, animal treatment with chemical chaperones that alleviated obesity-induced ER stress led to improvement in insulin sensitivity (Ozcan et al. 2006). The mechanism by which obesity leads to ER stress is not clear. One possibility is that ectopic lipid storage might trigger ER stress by sheer mechanical stress or perturbations in intracellular nutrient and energy fluxes, and severe changes in tissue architecture (Ozcan et al. 2004). Also, chronic elevation of FAs has been shown to induce ER stress (Karaskov et al. 2006). Finally, it is also possible that ER stress might lead to an increase in oxidative stress that in turn might contribute to the insulin resistance seen in the above studies (Haynes et al. 2004).

\section{Lessons learned from anti-diabetic drugs}

Thiazolidinediones (TZDs) represent a novel class of anti-diabetic agents that enhance hepatic and muscle insulin sensitivity in both humans and animals with obesity-associated T2DM (Rangwala and Lazar 2004; YkiJarvinen 2004). TZD action is primarily attributable to binding and activating PPAR $\gamma$, a nuclear receptor that is expressed at high levels in adipose tissue (Chawla et al. 1994; Tontonoz et al. 1994) and functions as the master regulator of adipocyte differentiation and metabolism (Lehmann et al. 1995; Spiegelman 1998; Lehrke and Lazar 2005). Many of the beneficial actions of TZDs can be explained by the repartitioning of FAs to adipose tissue and away from the muscles, liver, and circulation (Lehrke and Lazar 2005). TZDs also reduce the expression of adipokines that contribute to insulin resistance, while increasing the circulating levels of adiponectin (Sharma and Staels 2007). In addition, TZDs have antiinflammatory effects including transrepression of TNF $\alpha$ production by macrophages and decreased macrophage infiltration of adipose tissue (Xu et al. 2003; Di Gregorio et al. 2005; Pascual et al. 2005). Thus, the anti-diabetic effects of TZDs are due to the simultaneous reversal of many of the abnormalities that contribute to obesityassociated insulin resistance.

\section{Concluding remarks: too many choices on the menu or a poster child for systems biology?}

Obesity-associated insulin resistance is a complex disorder. Molecular biology research has made tremendous strides in discovering and delineating many more contributors to insulin resistance than were anticipated even a decade ago. Indeed, given the explosion of candidate molecules, systems, and pathways that have been shown to have the potential to cause insulin resistance, the view that one factor is primarily responsible for the link between obesity and insulin resistance is clearly simplistic. Multiple endocrine, inflammatory, and neural pathways are simultaneously disturbed and can further modulate signaling pathways that are cell-intrinsic (Fig. 2E) and functional in various metabolic tissues including fat, liver, and muscle, in addition to the immune and nervous systems. When one pathway is disturbed, its interconnections with the others lead to changes in other systems that exacerbate the problem. Furthermore, many of these pathways and mediators are involved in other serious diseases including tumors and autoimmune disorders. The present and future challenge is to determine which element(s) that are disturbed in the insulin-resistant milieu could be corrected with favorable metabolic outcomes without causing or exacerbating other diseases. This will require a detailed understanding of each system and how they are interconnected in humans.

\section{Acknowledgments}

We thank the NIDDK and the ADA for support of our research.

\section{References:}

Aguirre, V., Uchida, T., Yenush, L., Davis, R., and White, M.F. 2000. The c-Jun $\mathrm{NH}(2)$-terminal kinase promotes insulin resistance during association with insulin receptor substrate-1 and phosphorylation of Ser(307). J. Biol. Chem. 275: 90479054.

Arkan, M.C., Hevener, A.L., Greten, F.R., Maeda, S., Li, Z.W., Long, J.M., Wynshaw-Boris, A., Poli, G., Olefsky, J., and Karin, M. 2005. IKK- $\beta$ links inflammation to obesity-induced insulin resistance. Nat. Med. 11: 191-198.

Asilmaz, E., Cohen, P., Miyazaki, M., Dobrzyn, P., Ueki, K., Fayzikhodjaeva, G., Soukas, A.A., Kahn, C.R., Ntambi, J.M., Socci, N.D., et al. 2004. Site and mechanism of leptin action in a rodent form of congenital lipodystrophy. J. Clin. Invest. 113: 414-424.

Bak, J.F., Moller, N., Schmitz, O., Saaek, A., and Pedersen, O. 1992. In vivo insulin action and muscle glycogen synthase activity in type 2 (non-insulin-dependent) diabetes mellitus: Effects of diet treatment. Diabetologia 35: 777-784.

Banerjee, R.R., Rangwala, S.M., Shapiro, J.S., Rich, A.S., Rhoades, B., Qi, Y., Wang, J., Rajala, M.W., Pocai, A., Scherer, P.E., et al. 2004. Regulation of fasted blood glucose by resistin. Science 303: 1195-1198.

Bastard, J.P., Maachi, M., Van Nhieu, J.T., Jardel, C., Bruckert, E., Grimaldi, A., Robert, J.J., Capeau, J., and Hainque, B. 2002. Adipose tissue IL-6 content correlates with resistance to insulin activation of glucose uptake both in vivo and in 
vitro. J. Clin. Endocrinol. Metab. 87: 2084-2089.

Berg, A.H., Combs, T.P., Du, X., Brownlee, M., and Scherer, P.E. 2001. The adipocyte-secreted protein Acrp30 enhances hepatic insulin action. Nat. Med. 7: 947-953.

Bergman, R.N., Kim, S.P., Hsu, I.R., Catalano, K.J., Chiu, J.D., Kabir, M., Richey, J.M., and Ader, M. 2007. Abdominal obesity: Role in the pathophysiology of metabolic disease and cardiovascular risk. Am. J. Med. 120 (Suppl. 1): S3-S8.

Bernard, C. 1854. Leçons de physiologie expérimentale appliquées à la médecine. Baillere et fils, Paris.

Birnbaum, M.J. 2001. Turning down insulin signaling. J. Clin. Invest. 108: 655-659.

Bjorntorp, P., Bergman, H., and Varnauskas, E. 1969. Plasma free fatty acid turnover rate in obesity. Acta Med. Scand. 185: 351-356.

Blair, A.S., Hajduch, E., Litherland, G.J., and Hundal, H.S. 1999. Regulation of glucose transport and glycogen synthesis in L6 muscle cells during oxidative stress. Evidence for cross-talk between the insulin and SAPK2/p38 mitogen-activated protein kinase signaling pathways. J. Biol. Chem. 274: 3629336299.

Buettner, C., Patel, R., Muse, E.D., Bhanot, S., Monia, B.P., McKay, R., Obici, S., and Rossetti, L. 2005. Severe impairment in liver insulin signaling fails to alter hepatic insulin action in conscious mice. I. Clin. Invest. 115: 1306-1313.

Bujalska, I.J., Kumar, S., and Stewart, P.M. 1997. Does central obesity reflect 'Cushing's disease of the omentum'? Lancet 349: 1210-1213.

Burcelin, R., Kamohara, S., Li, J., Tannenbaum, G.S., Charron, M.J., and Friedman, J.M. 1999. Acute intravenous leptin infusion increases glucose turnover but not skeletal muscle glucose uptake in ob/ob mice. Diabetes 48: 1264-1269.

Cai, D., Yuan, M., Frantz, D.F., Melendez, P.A., Hansen, L., Lee, J., and Shoelson, S.E. 2005. Local and systemic insulin resistance resulting from hepatic activation of IKK- $\beta$ and NF-кB. Nat. Med. 11: 183-190.

Carlsson, C., Borg, L.A., and Welsh, N. 1999. Sodium palmitate induces partial mitochondrial uncoupling and reactive oxygen species in rat pancreatic islets in vitro. Endocrinology 140: 3422-3428.

Carswell, E.A., Old, L.J., Kassel, R.L., Green, S., Fiore, N., and Williamson, B. 1975. An endotoxin-induced serum factor that causes necrosis of tumors. Proc. Natl. Acad. Sci. 72: 3666-3670.

Chandran, M., Phillips, S.A., Ciaraldi, T., and Henry, R.R. 2003. Adiponectin: More than just another fat cell hormone? Diabetes Care 26: 2442-2450.

Chawla, A., Schwarz, E.J., Dimaculangan, D.D., and Lazar, M.A. 1994. Peroxisome proliferator-activated receptor (PPAR) $\gamma$ : Adipose-predominant expression and induction early in adipocyte differentiation. Endocrinology 135: 798-800.

Cheung, A.T., Ree, D., Kolls, J.K., Fuselier, J., Coy, D.H., and Bryer-Ash, M. 1998. An in vivo model for elucidation of the mechanism of tumor necrosis factor- $\alpha$ (TNF- $\alpha$ )-induced insulin resistance: Evidence for differential regulation of insulin signaling by TNF- $\alpha$. Endocrinology 139: 4928-4935.

Choi-Miura, N.H., Tobe, T., Sumiya, J., Nakano, Y., Sano, Y., Mazda, T., and Tomita, M. 1996. Purification and characterization of a novel hyaluronan-binding protein (PHBP) from human plasma: It has three EGF, a kringle and a serine protease domain, similar to hepatocyte growth factor activator. J. Biochem. 119: 1157-1165.

Combs, T.P., Pajvani, U.B., Berg, A.H., Lin, Y., Jelicks, L.A., Laplante, M., Nawrocki, A.R., Rajala, M.W., Parlow, A.F., Cheeseboro, L., et al. 2004. A transgenic mouse with a deletion in the collagenous domain of adiponectin displays el- evated circulating adiponectin and improved insulin sensitivity. Endocrinology 145: 367-383.

Dandona, P., Aljada, A., and Bandyopadhyay, A. 2004. Inflammation: The link between insulin resistance, obesity and diabetes. Trends Immunol. 25: 4-7.

DeFronzo, R.A. 2004. Pathogenesis of type 2 diabetes mellitus. Med. Clin. North Am. 88: 787-835.

Di Gregorio, G.B., Yao-Borengasser, A., Rasouli, N., Varma, V., Lu, T., Miles, L.M., Ranganathan, G., Peterson, C.A., McGehee, R.E., and Kern, P.A. 2005. Expression of CD68 and macrophage chemoattractant protein-1 genes in human adipose and muscle tissues: Association with cytokine expression, insulin resistance, and reduction by pioglitazone. Diabetes 54: 2305-2313.

Diez, J.J. and Iglesias, P. 2003. The role of the novel adipocytederived hormone adiponectin in human disease. Eur. J. Endocrinol. 148: 293-300.

Ebihara, K., Ogawa, Y., Masuzaki, H., Shintani, M., Miyanaga, F., Aizawa-Abe, M., Hayashi, T., Hosoda, K., Inoue, G., Yoshimasa, Y., et al. 2001. Transgenic overexpression of leptin rescues insulin resistance and diabetes in a mouse model of lipoatrophic diabetes. Diabetes 50: 1440-1448.

Emanuelli, B., Peraldi, P., Filloux, C., Chavey, C., Freidinger, K., Hilton, D.J., Hotamisligil, G.S., and Van Obberghen, E. 2001. SOCS-3 inhibits insulin signaling and is up-regulated in response to tumor necrosis factor- $\alpha$ in the adipose tissue of obese mice. J. Biol. Chem. 276: 47944-47949.

Evans, J.L., Goldfine, I.D., Maddux, B.A., and Grodsky, G.M. 2002. Oxidative stress and stress-activated signaling pathways: A unifying hypothesis of type 2 diabetes. Endocr. Rev. 23: 599-622.

Evans, J.L., Goldfine, I.D., Maddux, B.A., and Grodsky, G.M. 2003. Are oxidative stress-activated signaling pathways mediators of insulin resistance and $\beta$-cell dysfunction? Diabetes 52: $1-8$.

Fain, J.N., Madan, A.K., Hiler, M.L., Cheema, P., and Bahouth, S.W. 2004. Comparison of the release of adipokines by adipose tissue, adipose tissue matrix, and adipocytes from visceral and subcutaneous abdominal adipose tissues of obese humans. Endocrinology 145: 2273-2282.

Fernandez-Real, J.M. and Ricart, W. 2003. Insulin resistance and chronic cardiovascular inflammatory syndrome. Endocr. Rev. 24: 278-301

Fontana, L., Eagon, J.C., Trujillo, M.E., Scherer, P.E., and Klein, S. 2007. Visceral fat adipokine secretion is associated with systemic inflammation in obese humans. Diabetes 56: 1010-1013.

Freidenberg, G.R., Reichart, D., Olefsky, J.M., and Henry, R.R. 1988. Reversibility of defective adipocyte insulin receptor kinase activity in non-insulin-dependent diabetes mellitus. Effect of weight loss. J. Clin. Invest. 82: 1398-1406.

Fridlyand, L.E. and Philipson, L.H. 2006. Reactive species and early manifestation of insulin resistance in type 2 diabetes. Diabetes Obes. Metab. 8: 136-145.

Fruebis, J., Tsao, T.S., Javorschi, S., Ebbets-Reed, D., Erickson, M.R., Yen, F.T., Bihain, B.E., and Lodish, H.F. 2001. Proteolytic cleavage product of $30-\mathrm{kDa}$ adipocyte complement-related protein increases fatty acid oxidation in muscle and causes weight loss in mice. Proc. Nat1. Acad. Sci. 98: 20052010.

Furukawa, S., Fujita, T., Shimabukuro, M., Iwaki, M., Yamada, Y., Nakajima, Y., Nakayama, O., Makishima, M., Matsuda, M., and Shimomura, I. 2004. Increased oxidative stress in obesity and its impact on metabolic syndrome. J. Clin. Invest. 114: 1752-1761.

Gao, Z., Hwang, D., Bataille, F., Lefevre, M., York, D., Quon, 
M.J., and Ye, J. 2002. Serine phosphorylation of insulin receptor substrate 1 by inhibitor кB kinase complex. J. Biol. Chem. 277: 48115-48121.

Gao, Z., Zhang, X., Zuberi, A., Hwang, D., Quon, M.J., Lefevre, M., and Ye, J. 2004. Inhibition of insulin sensitivity by free fatty acids requires activation of multiple serine kinases in 3T3-L1 adipocytes. Mol. Endocrinol. 18: 2024-2034.

Gavi, S., Stuart, L.M., Kelly, P., Melendez, M.M., Mynarcik, D.C., Gelato, M.C., and McNurlan, M.A. 2007. Retinolbinding protein 4 is associated with insulin resistance and body fat distribution in nonobese subjects without type 2 diabetes. J. Clin. Endocrinol. Metab. 92: 1886-1890.

Gesta, S., Bluher, M., Yamamoto, Y., Norris, A.W., Berndt, J., Kralisch, S., Boucher, J., Lewis, C., and Kahn, C.R. 2006. Evidence for a role of developmental genes in the origin of obesity and body fat distribution. Proc. Natl. Acad. Sci. 103: 6676-6681.

Gordon, E.S. 1964. Lipid metabolism, diabetes mellitus, And obesity. Adv. Intern. Med. 12: 66-102.

Graham, T.E., Yang, Q., Bluher, M., Hammarstedt, A., Ciaraldi, T.P., Henry, R.R., Wason, C.J., Oberbach, A., Jansson, P.A., Smith, U., et al. 2006. Retinol-binding protein 4 and insulin resistance in lean, obese, and diabetic subjects. N. Engl. J. Med. 354: 2552-2563.

Haber, C.A., Lam, T.K., Yu, Z., Gupta, N., Goh, T., Bogdanovic, E., Giacca, A., and Fantus, I.G. 2003. N-acetylcysteine and taurine prevent hyperglycemia-induced insulin resistance in vivo: Possible role of oxidative stress. Am. J. Physiol. Endocrinol. Metab. doi: 10.1152/ajpendo.00355.2002.

Halliwell, B. 1995. Antioxidant characterization. Methodology and mechanism. Biochem. Pharmacol. 49: 1341-1348.

Hautanen, A., Raikkonen, K., and Adlercreutz, H. 1997. Associations between pituitary-adrenocortical function and abdominal obesity, hyperinsulinaemia and dyslipidaemia in normotensive males. J. Intern. Med. 241: 451-461.

Haynes, C.M., Titus, E.A., and Cooper, A.A. 2004. Degradation of misfolded proteins prevents ER-derived oxidative stress and cell death. Mol. Cell 15: 767-776.

Hirosumi, J., Tuncman, G., Chang, L., Gorgun, C.Z., Uysal, K.T., Maeda, K., Karin, M., and Hotamisligil, G.S. 2002. A central role for JNK in obesity and insulin resistance. Nature 420: 333-336.

Holcomb, I.N., Kabakoff, R.C., Chan, B., Baker, T.W., Gurney, A., Henzel, W., Nelson, C., Lowman, H.B., Wright, B.D., Skelton, N.J., et al. 2000. FIZZ1, a novel cysteine-rich secreted protein associated with pulmonary inflammation, defines a new gene family. EMBO J. 19: 4046-4055.

Hotamisligil, G.S. 2003. Inflammatory pathways and insulin action. Int. J. Obes. Relat. Metab. Disord. 27 (Suppl. 3): S53S55.

Hotamisligil, G.S., Shargill, N.S., and Spiegelman, B.M. 1993. Adipose expression of tumor necrosis factor- $\alpha$ : Direct role in obesity-linked insulin resistance. Science 259: 87-91.

Hotamisligil, G.S., Arner, P., Caro, J.F., Atkinson, R.L., and Spiegelman, B.M. 1995. Increased adipose tissue expression of tumor necrosis factor- $\alpha$ in human obesity and insulin resistance. J. Clin. Invest. 95: 2409-2415.

Hotamisligil, G.S., Peraldi, P., Budavari, A., Ellis, R., White, M.F., and Spiegelman, B.M. 1996. IRS-1-mediated inhibition of insulin receptor tyrosine kinase activity in TNF- $\alpha$ - and obesity-induced insulin resistance. Science 271: 665-668.

Houstis, N., Rosen, E.D., and Lander, E.S. 2006. Reactive oxygen species have a causal role in multiple forms of insulin resistance. Nature 440: 944-948.

Howard, J.K., Cave, B.J., Oksanen, L.J., Tzameli, I., Bjorbaek, C., and Flier, J.S. 2004. Enhanced leptin sensitivity and attenu- ation of diet-induced obesity in mice with haploinsufficiency of Socs3. Nat. Med. 10: 734-738.

Hribal, M.L., Oriente, F., and Accili, D. 2002. Mouse models of insulin resistance. Am. J. Physiol. Endocrinol. Metab. doi: 10.1152/ajpendo.00561.2001.

Hu, E., Liang, P., and Spiegelman, B.M. 1996. AdipoQ is a novel adipose-specific gene dysregulated in obesity. J. Biol. Chem. 271: 10697-10703.

Hundal, R.S., Petersen, K.F., Mayerson, A.B., Randhawa, P.S., Inzucchi, S., Shoelson, S.E., and Shulman, G.I. 2002. Mechanism by which high-dose aspirin improves glucose metabolism in type 2 diabetes. J. Clin. Invest. 109: 1321-1326.

Ingalls, A.M., Dickie, M.M., and Snell, G.D. 1950. Obese, a new mutation in the house mouse. J. Hered. 41: 317-318.

Jacob, S., Ruus, P., Hermann, R., Tritschler, H.J., Maerker, E., Renn, W., Augustin, H.J., Dietze, G.J., and Rett, K. 1999. Oral administration of RAC- $\alpha$-lipoic acid modulates insulin sensitivity in patients with type- 2 diabetes mellitus: A placebo-controlled pilot trial. Free Radic. Biol. Med. 27: 309314.

Jacobson, P.B., von Geldern, T.W., Ohman, L., Osterland, M., Wang, J., Zinker, B., Wilcox, D., Nguyen, P.T., Mika, A., Fung, S., et al. 2005. Hepatic glucocorticoid receptor antagonism is sufficient to reduce elevated hepatic glucose output and improve glucose control in animal models of type 2 diabetes. J. Pharmacol. Exp. Ther. 314: 191-200.

Janke, J., Engeli, S., Gorzelniak, K., Luft, F.C., and Sharma, A.M. 2002. Resistin gene expression in human adipocytes is not related to insulin resistance. Obes. Res. 10: 1-5.

Janke, J., Engeli, S., Boschmann, M., Adams, F., Bohnke, J., Luft, F.C., Sharma, A.M., and Jordan, J. 2006. Retinol-binding protein 4 in human obesity. Diabetes 55: 2805-2810.

Jensen, M.D., Haymond, M.W., Rizza, R.A., Cryer, P.E., and Miles, J.M. 1989. Influence of body fat distribution on free fatty acid metabolism in obesity. J. Clin. Invest. 83: 11681173.

Juhan-Vague, I., Alessi, M.C., Mavri, A., and Morange, P.E. 2003. Plasminogen activator inhibitor-1, inflammation, obesity, insulin resistance and vascular risk. I. Thromb. Haemost. 1: 1575-1579.

Kabir, M., Catalano, K.J., Ananthnarayan, S., Kim, S.P., Van Citters, G.W., Dea, M.K., and Bergman, R.N. 2005. Molecular evidence supporting the portal theory: A causative link between visceral adiposity and hepatic insulin resistance. Am. I. Physiol. Endocrinol. Metab. doi: 10.1152/ ajpendo.00203.2004.

Kanda, H., Tateya, S., Tamori, Y., Kotani, K., Hiasa, K., Kitazawa, R., Kitazawa, S., Miyachi, H., Maeda, S., Egashira, K., et al. 2006. MCP-1 contributes to macrophage infiltration into adipose tissue, insulin resistance, and hepatic steatosis in obesity. J. Clin. Invest. 116: 1494-1505.

Karaskov, E., Scott, C., Zhang, L., Teodoro, T., Ravazzola, M., and Volchuk, A. 2006. Chronic palmitate but not oleate exposure induces endoplasmic reticulum stress, which may contribute to INS- 1 pancreatic $\beta$-cell apoptosis. Endocrinology 147: 3398-3407.

Kershaw, E.E. and Flier, J.S. 2004. Adipose tissue as an endocrine organ. J. Clin. Endocrinol. Metab. 89: 2548-2556.

Khamaisi, M., Potashnik, R., Tirosh, A., Demshchak, E., Rudich, A., Tritschler, H., Wessel, K., and Bashan, N. 1997. Lipoic acid reduces glycemia and increases muscle GLUT4 content in streptozotocin-diabetic rats. Metabolism 46: 763768.

Kielstein, J.T., Becker, B., Graf, S., Brabant, G., Haller, H., and Fliser, D. 2003. Increased resistin blood levels are not associated with insulin resistance in patients with renal disease. 
Am. J. Kidney Dis. 42: 62-66.

Kim, K.H., Lee, K., Moon, Y.S., and Sul, H.S. 2001. A cysteinerich adipose tissue-specific secretory factor inhibits adipocyte differentiation. J. Biol. Chem. 276: 11252-11256.

Konrad, T., Vicini, P., Kusterer, K., Hoflich, A., Assadkhani, A., Bohles, H.J., Sewell, A., Tritschler, H.J., Cobelli, C., and Usadel, K.H. 1999. $\alpha$-Lipoic acid treatment decreases serum lactate and pyruvate concentrations and improves glucose effectiveness in lean and obese patients with type 2 diabetes. Diabetes Care 22: 280-287.

Kubota, N., Terauchi, Y., Yamauchi, T., Kubota, T., Moroi, M., Matsui, J., Eto, K., Yamashita, T., Kamon, J., Satoh, H., et al. 2002. Disruption of adiponectin causes insulin resistance and neointimal formation. J. Biol. Chem. 277: 25863-25866.

Kyriakis, J.M. and Avruch, J. 1996. Sounding the alarm: Protein kinase cascades activated by stress and inflammation. J. Biol. Chem. 271: 24313-24316.

Lagouge, M., Argmann, C., Gerhart-Hines, Z., Meziane, H., Lerin, C., Daussin, F., Messadeq, N., Milne, J., Lambert, P., Elliott, P., et al. 2006. Resveratrol improves mitochondrial function and protects against metabolic disease by activating SIRT1 and PGC-1 1 . Cell 127: 1109-1122.

Lehmann, J.M., Moore, L.B., Smith-Oliver, T.A., Wilkison, W.O., Willson, T.M., and Kliewer, S.A. 1995. An antidiabetic thiazolidinedione is a high affinity ligand for peroxisome proliferator-activated receptor $\gamma(\operatorname{PPAR} \gamma)$. J. Biol. Chem. 270: 12953-12956.

Lehrke, M. and Lazar, M.A. 2005. The many faces of PPAR $\gamma$. Cell 123: 993-999.

Lehrke, M., Reilly, M.P., Millington, S.C., Iqbal, N., Rader, D.J., and Lazar, M.A. 2004. An inflammatory cascade leading to hyperresistinemia in humans. PLoS Med. doi: 10.1371/ journal.pmed.0010045.

Li, Z., Bowerman, S., and Heber, D. 2005. Health ramifications of the obesity epidemic. Surg. Clin. North Am. 85: 681-701.

Livingstone, D.E., Jones, G.C., Smith, K., Jamieson, P.M., Andrew, R., Kenyon, C.J., and Walker, B.R. 2000. Understanding the role of glucocorticoids in obesity: Tissue-specific alterations of corticosterone metabolism in obese Zucker rats. Endocrinology 141: 560-563.

Lumeng, C.N., Bodzin, J.L., and Saltiel, A.R. 2007. Obesity induces a phenotypic switch in adipose tissue macrophage polarization. J. Clin. Invest. 117: 175-184.

Ma, L.J., Mao, S.L., Taylor, K.L., Kanjanabuch, T., Guan, Y., Zhang, Y., Brown, N.J., Swift, L.L., McGuinness, O.P., Wasserman, D.H., et al. 2004. Prevention of obesity and insulin resistance in mice lacking plasminogen activator inhibitor 1. Diabetes 53: 336-346.

Maddux, B.A., See, W., Lawrence Jr., J.C., Goldfine, A.L., Goldfine, I.D., and Evans, J.L. 2001. Protection against oxidative stress-induced insulin resistance in rat L6 muscle cells by mircomolar concentrations of $\alpha$-lipoic acid. Diabetes 50: 404-410.

Maeda, K., Okubo, K., Shimomura, I., Funahashi, T., Matsuzawa, Y., and Matsubara, K. 1996. cDNA cloning and expression of a novel adipose specific collagen-like factor, apM1 (AdiPose Most abundant Gene transcript 1). Biochem. Biophys. Res. Commun. 221: 286-289.

Maeda, N., Shimomura, I., Kishida, K., Nishizawa, H., Matsuda, M., Nagaretani, H., Furuyama, N., Kondo, H., Takahashi, M., Arita, Y., et al. 2002. Diet-induced insulin resistance in mice lacking adiponectin/ACRP30. Nat. Med. 8: 731-737.

Masuzaki, H., Paterson, J., Shinyama, H., Morton, N.M., Mullins, J.J., Seckl, J.R., and Flier, J.S. 2001. A transgenic model of visceral obesity and the metabolic syndrome. Science 294: 2166-2170.
Matsuzawa, A., Saegusa, K., Noguchi, T., Sadamitsu, C., Nishitoh, H., Nagai, S., Koyasu, S., Matsumoto, K., Takeda, K., and Ichijo, H. 2005. ROS-dependent activation of the TRAF6-ASK1-p38 pathway is selectively required for TLR4mediated innate immunity. Nat. Immunol. 6: 587-592.

McGarry, J.D. 2002. Banting lecture 2001: Dysregulation of fatty acid metabolism in the etiology of type 2 diabetes. Diabetes 51: 7-18.

McTernan, C.L., McTernan, P.G., Harte, A.L., Levick, P.L., Barnett, A.H., and Kumar, S. 2002. Resistin, central obesity, and type 2 diabetes. Lancet 359: 46-47.

McTernan, P.G., McTernan, C.L., Chetty, R., Jenner, K., Fisher, F.M., Lauer, M.N., Crocker, J., Barnett, A.H., and Kumar, S. 2002. Increased resistin gene and protein expression in human abdominal adipose tissue. J. Clin. Endocrinol. Metab. 87: 2407-2410.

Mensink, M., Hesselink, M.K., Russell, A.P., Schaart, G., Sels, J.P., and Schrauwen, P. 2007. Improved skeletal muscle oxidative enzyme activity and restoration of PGC- $1 \alpha$ and $\operatorname{PPAR} \beta / \delta$ gene expression upon rosiglitazone treatment in obese patients with type 2 diabetes mellitus. Int. J. Obes. (Lond.) doi: 10.1038/sj.ijo.0803567.

Mertens, I. and Van Gaal, L.F. 2002. Obesity, haemostasis and the fibrinolytic system. Obes. Rev. 3: 85-101.

Miyazaki, Y., Pipek, R., Mandarino, L.J., and DeFronzo, R.A. 2003. Tumor necrosis factor $\alpha$ and insulin resistance in obese type 2 diabetic patients. Int. J. Obes. Relat. Metab. Disord. 27: 88-94.

Mooney, R.A., Senn, J., Cameron, S., Inamdar, N., Boivin, L.M., Shang, Y., and Furlanetto, R.W. 2001. Suppressors of cytokine signaling- 1 and -6 associate with and inhibit the insulin receptor. A potential mechanism for cytokine-mediated insulin resistance. J. Biol. Chem. 276: 25889-25893.

Mootha, V.K., Lindgren, C.M., Eriksson, K.F., Subramanian, A., Sihag, S., Lehar, J., Puigserver, P., Carlsson, E., Ridderstrale, M., Laurila, E., et al. 2003. PGC- $1 \alpha$-responsive genes involved in oxidative phosphorylation are coordinately downregulated in human diabetes. Nat. Genet. 34: 267-273.

Mori, H., Hanada, R., Hanada, T., Aki, D., Mashima, R., Nishinakamura, H., Torisu, T., Chien, K.R., Yasukawa, H., and Yoshimura, A. 2004. Socs3 deficiency in the brain elevates leptin sensitivity and confers resistance to diet-induced obesity. Nat. Med. 10: 739-743.

Nakatani, Y., Kaneto, H., Kawamori, D., Hatazaki, M., Miyatsuka, T., Matsuoka, T.A., Kajimoto, Y., Matsuhisa, M., Yamasaki, Y., and Hori, M. 2004. Modulation of the JNK pathway in liver affects insulin resistance status. J. Biol. Chem. 279: 45803-45809.

Nakatani, Y., Kaneto, H., Kawamori, D., Yoshiuchi, K., Hatazaki, M., Matsuoka, T.A., Ozawa, K., Ogawa, S., Hori, M., Yamasaki, Y., et al. 2005. Involvement of endoplasmic reticulum stress in insulin resistance and diabetes. J. Biol. Chem. 280: 847-851.

Nilsson, J., Jovinge, S., Niemann, A., Reneland, R., and Lithell, H. 1998. Relation between plasma tumor necrosis factor- $\alpha$ and insulin sensitivity in elderly men with non-insulin-dependent diabetes mellitus. Arterioscler. Thromb. Vasc. Biol. 18: 1199-1202.

Niswender, K.D., Morton, G.J., Stearns, W.H., Rhodes, C.J., Myers Jr., M.G., and Schwartz, M.W. 2001. Intracellular signalling. Key enzyme in leptin-induced anorexia. Nature 413: 794-795

Obici, S., Feng, Z., Karkanias, G., Baskin, D.G., and Rossetti, L. 2002a. Decreasing hypothalamic insulin receptors causes hyperphagia and insulin resistance in rats. Nat. Neurosci. 5: $566-572$ 
Obici, S., Feng, Z., Morgan, K., Stein, D., Karkanias, G., and Rossetti, L. 2002b. Central administration of oleic acid inhibits glucose production and food intake. Diabetes 51: 271275.

Obici, S., Zhang, B.B., Karkanias, G., and Rossetti, L. 2002c. Hypothalamic insulin signaling is required for inhibition of glucose production. Nat. Med. 8: 1376-1382.

Obici, S., Feng, Z., Arduini, A., Conti, R., and Rossetti, L. 2003. Inhibition of hypothalamic carnitine palmitoyltransferase-1 decreases food intake and glucose production. Nat. Med. 9: 756-761.

Okamoto, H., Nakae, J., Kitamura, T., Park, B.C., Dragatsis, I., and Accili, D. 2004. Transgenic rescue of insulin receptordeficient mice. J. Clin. Invest. 114: 214-223.

Olshansky, S.J. 2005. Projecting the future of U.S. health and longevity. Health Aff. (Millwood) 24: 86-89.

Osawa, H., Yamada, K., Onuma, H., Murakami, A., Ochi, M., Kawata, H., Nishimiya, T., Niiya, T., Shimizu, I., Nishida, $\mathrm{W}$., et al. 2004. The G/G genotype of a resistin single-nucleotide polymorphism at -420 increases type 2 diabetes mellitus susceptibility by inducing promoter activity through specific binding of Sp1/3. Am. J. Hum. Genet. 75: 678-686.

Osawa, H., Onuma, H., Ochi, M., Murakami, A., Yamauchi, J., Takasuka, T., Tanabe, F., Shimizu, I., Kato, K., Nishida, W., et al. 2005. Resistin SNP-420 determines its monocyte mRNA and serum levels inducing type 2 diabetes. Biochem. Biophys. Res. Commun. 335: 596-602.

Ozawa, K., Miyazaki, M., Matsuhisa, M., Takano, K., Nakatani, Y., Hatazaki, M., Tamatani, T., Yamagata, K., Miyagawa, J., Kitao, Y., et al. 2005. The endoplasmic reticulum chaperone improves insulin resistance in type 2 diabetes. Diabetes 54 : 657-663.

Ozcan, U., Cao, Q., Yilmaz, E., Lee, A.H., Iwakoshi, N.N., Ozdelen, E., Tuncman, G., Gorgun, C., Glimcher, L.H., and Hotamisligil, G.S. 2004. Endoplasmic reticulum stress links obesity, insulin action, and type 2 diabetes. Science 306: 457-461.

Ozcan, U., Yilmaz, E., Ozcan, L., Furuhashi, M., Vaillancourt, E., Smith, R.O., Gorgun, C.Z., and Hotamisligil, G.S. 2006. Chemical chaperones reduce ER stress and restore glucose homeostasis in a mouse model of type 2 diabetes. Science 313: $1137-1140$.

Pang, S.S. and Le, Y.Y. 2006. Role of resistin in inflammation and inflammation-related diseases. Cell. Mol. Immunol. 3: 29-34.

Paolisso, G. and Giugliano, D. 1996. Oxidative stress and insulin action: Is there a relationship? Diabetologia 39: 357-363.

Paolisso, G., Di Maro, G., Pizza, G., D'Amore, A., Sgambato, S., Tesauro, P., Varricchio, M., and D'Onofrio, F. 1992. Plasma GSH/GSSG affects glucose homeostasis in healthy subjects and non-insulin-dependent diabetics. Am. J. Physiol. 263: E435-E440.

Paolisso, G., Gambardella, A., Tagliamonte, M.R., Saccomanno, F., Salvatore, T., Gualdiero, P., D'Onofrio, M.V., and Howard, B.V. 1996. Does free fatty acid infusion impair insulin action also through an increase in oxidative stress? $J$. Clin. Endocrinol. Metab. 81: 4244-4248.

Pascual, G., Fong, A.L., Ogawa, S., Gamliel, A., Li, A.C., Perissi, V., Rose, D.W., Willson, T.M., Rosenfeld, M.G., and Glass, C.K. 2005. A SUMOylation-dependent pathway mediates transrepression of inflammatory response genes by PPAR- $\gamma$. Nature 437: 759-763.

Patel, L., Buckels, A.C., Kinghorn, I.J., Murdock, P.R., Holbrook, J.D., Plumpton, C., Macphee, C.H., and Smith, S.A. 2003. Resistin is expressed in human macrophages and directly regulated by PPAR $\gamma$ activators. Biochem. Biophys.
Res. Commun. 300: 472-476.

Patti, M.E., Butte, A.J., Crunkhorn, S., Cusi, K., Berria, R., Kashyap, S., Miyazaki, Y., Kohane, I., Costello, M., Saccone, R., et al. 2003. Coordinated reduction of genes of oxidative metabolism in humans with insulin resistance and diabetes: Potential role of PGC1 and NRF1. Proc. Natl. Acad. Sci. 100: 8466-8471.

Paulmyer-Lacroix, O., Boullu, S., Oliver, C., Alessi, M.C., and Grino, M. 2002. Expression of the mRNA coding for $11 \beta$ hydroxysteroid dehydrogenase type 1 in adipose tissue from obese patients: An in situ hybridization study. J. Clin. Endocrinol. Metab. 87: 2701-2705.

Petersen, K.F. and Shulman, G.I. 2006. Etiology of insulin resistance. Am. J. Med. 119 (Suppl. 1): S10-S16.

Petersen, K.F., Befroy, D., Dufour, S., Dziura, J., Ariyan, C., Rothman, D.L., DiPietro, L., Cline, G.W., and Shulman, G.I. 2003. Mitochondrial dysfunction in the elderly: Possible role in insulin resistance. Science 300: 1140-1142.

Petersen, K.F., Dufour, S., Befroy, D., Garcia, R., and Shulman, G.I. 2004. Impaired mitochondrial activity in the insulinresistant offspring of patients with type 2 diabetes. N. Engl. J. Med. 350: 664-671.

Petersen, E.W., Carey, A.L., Sacchetti, M., Steinberg, G.R., Macaulay, S.L., Febbraio, M.A., and Pedersen, B.K. 2005. Acute IL-6 treatment increases fatty acid turnover in elderly humans in vivo and in tissue culture in vitro. Am. J. Physiol. Endocrinol. Metab. doi: 10.1152/ajpendo.00257.2004.

Pocai, A., Morgan, K., Buettner, C., Gutierrez-Juarez, R., Obici, S., and Rossetti, L. 2005a. Central leptin acutely reverses diet-induced hepatic insulin resistance. Diabetes 54: 31823189.

Pocai, A., Obici, S., Schwartz, G.J., and Rossetti, L. 2005b. A brain-liver circuit regulates glucose homeostasis. Cell Metab. 1: 53-61.

Pocai, A., Lam, T.K., Obici, S., Gutierrez-Juarez, R., Muse, E.D., Arduini, A., and Rossetti, L. 2006. Restoration of hypothalamic lipid sensing normalizes energy and glucose homeostasis in overfed rats. J. Clin. Invest. 116: 1081-1091.

Qi, Y., Nie, Z., Lee, Y.S., Singhal, N.S., Scherer, P.E., Lazar, M.A., and Ahima, R.S. 2006. Loss of resistin improves glucose homeostasis in leptin deficiency. Diabetes 55: 3083 3090.

Rajala, M.W. and Scherer, P.E. 2003. Minireview: The adipocyte-At the crossroads of energy homeostasis, inflammation, and atherosclerosis. Endocrinology 144: 3765-3773.

Rajala, M.W., Obici, S., Scherer, P.E., and Rossetti, L. 2003. Adipose-derived resistin and gut-derived resistin-like molecule- $\beta$ selectively impair insulin action on glucose production. J. Clin. Invest. 111: 225-230.

Randle, P.J., Garland, P.B., Hales, C.N., and Newsholme, E.A. 1963. The glucose fatty-acid cycle. Its role in insulin sensitivity and the metabolic disturbances of diabetes mellitus. Lancet 1: 785-789.

Rangwala, S.M. and Lazar, M.A. 2004. Peroxisome proliferatoractivated receptor $\gamma$ in diabetes and metabolism. Trends Pharmacol. Sci. 25: 331-336.

Rangwala, S.M., Rich, A.S., Rhoades, B., Shapiro, J.S., Obici, S., Rossetti, L., and Lazar, M.A. 2004. Abnormal glucose homeostasis due to chronic hyperresistinemia. Diabetes 53: 1937-1941.

Rao, M.S. and Reddy, J.K. 2001. Peroxisomal $\beta$-oxidation and steatohepatitis. Semin. Liver Dis. 21: 43-55.

Rask, E., Olsson, T., Soderberg, S., Andrew, R., Livingstone, D.E., Johnson, O., and Walker, B.R. 2001. Tissue-specific dysregulation of cortisol metabolism in human obesity. $J$. Clin. Endocrinol. Metab. 86: 1418-1421. 
Reaven, G.M. and Chen, Y.D. 1996. Insulin resistance, its consequences, and coronary heart disease. Must we choose one culprit? Circulation 93: 1780-1783.

Reilly, M.P., Lehrke, M., Wolfe, M.L., Rohatgi, A., Lazar, M.A., and Rader, D.J. 2005. Resistin is an inflammatory marker of atherosclerosis in humans. Circulation 111: 932-939.

Rieusset, J., Bouzakri, K., Chevillotte, E., Ricard, N., Jacquet, D., Bastard, J.P., Laville, M., and Vidal, H. 2004. Suppressor of cytokine signaling 3 expression and insulin resistance in skeletal muscle of obese and type 2 diabetic patients. Diabetes 53: 2232-2241.

Rosen, P., Nawroth, P.P., King, G., Moller, W., Tritschler, H.J., and Packer, L. 2001. The role of oxidative stress in the onset and progression of diabetes and its complications: A summary of a Congress Series sponsored by UNESCO-MCBN, the American Diabetes Association and the German Diabetes Society. Diabetes Metab. Res. Rev. 17: 189-212.

Ruan, H. and Lodish, H.F. 2003. Insulin resistance in adipose tissue: Direct and indirect effects of tumor necrosis factor- $\alpha$. Cytokine Growth Factor Rev. 14: 447-455.

Rui, L., Yuan, M., Frantz, D., Shoelson, S., and White, M.F. 2002. SOCS-1 and SOCS-3 block insulin signaling by ubiquitin-mediated degradation of IRS1 and IRS2. J. Biol. Chem. 277: 42394-42398.

Ryden, M., Dicker, A., van Harmelen, V., Hauner, H., Brunnberg, M., Perbeck, L., Lonnqvist, F., and Arner, P. 2002. Mapping of early signaling events in tumor necrosis factor- $\alpha$ mediated lipolysis in human fat cells. J. Biol. Chem. 277: 1085-1091.

Saltiel, A.R. and Kahn, C.R. 2001. Insulin signalling and the regulation of glucose and lipid metabolism. Nature 414: 799806.

Satoh, H., Nguyen, M.T., Miles, P.D., Imamura, T., Usui, I., and Olefsky, J.M. 2004. Adenovirus-mediated chronic 'hyper-resistinemia' leads to in vivo insulin resistance in normal rats. J. Clin. Invest. 114: 224-231.

Savage, D.B., Sewter, C.P., Klenk, E.S., Segal, D.G., Vidal-Puig, A., Considine, R.V., and O'Rahilly, S. 2001. Resistin/Fizz3 expression in relation to obesity and peroxisome proliferator-activated receptor- $\gamma$ action in humans. Diabetes 50: 2199-2202.

Scherer, P.E., Williams, S., Fogliano, M., Baldini, G., and Lodish, H.F. 1995. A novel serum protein similar to C1q, produced exclusively in adipocytes. J. Biol. Chem. 270: 26746-26749.

Seckl, J.R., Morton, N.M., Chapman, K.E., and Walker, B.R. 2004. Glucocorticoids and $11 \beta$-hydroxysteroid dehydrogenase in adipose tissue. Recent Prog. Horm. Res. 59: 359-393.

Seeley, R.J. and Woods, S.C. 2003. Monitoring of stored and available fuel by the CNS: Implications for obesity. Nat. Rev. Neurosci. 4: 901-909.

Senolt, L., Housa, D., Vernerova, Z., Jirasek, T., Svobodova, R., Veigl, D., Anderlova, K., Muller-Ladner, U., Pavelka, K., and Haluzik, M. 2006. Resistin is abundantly present in rheumatoid arthritis synovial tissue, synovial fluid, and elevated serum resistin reflects disease activity. Ann. Rheum. Dis. doi: 10.1136/ard.2006.054734.

Sharma, A.M. and Staels, B. 2007. Review: Peroxisome proliferator-activated receptor $\gamma$ and adipose tissue-Understanding obesity-related changes in regulation of lipid and glucose metabolism. J. Clin. Endocrinol. Metab. 92: 386-395.

Shi, H., Tzameli, I., Bjorbaek, C., and Flier, J.S. 2004. Suppressor of cytokine signaling 3 is a physiological regulator of adipocyte insulin signaling. J. Biol. Chem. 279: 34733-34740.

Shi, H., Kokoeva, M.V., Inouye, K., Tzameli, I., Yin, H., and Flier, J.S. 2006. TLR4 links innate immunity and fatty acidinduced insulin resistance. J. Clin. Invest. 116: 3015-3025.
Shoelson, S.E., Lee, J., and Yuan, M. 2003. Inflammation and the IKK $\beta /$ Iк B/NF-к B axis in obesity- and diet-induced insulin resistance. Int. J. Obes. Relat. Metab. Disord. 27 (Suppl. 3): S49-S52.

Shoelson, S.E., Lee, J., and Goldfine, A.B. 2006. Inflammation and insulin resistance. J. Clin. Invest. 116: 1793-1801.

Shulman, G.I. 2000. Cellular mechanisms of insulin resistance. J. Clin. Invest. 106: 171-176.

Sims, E.A., Danforth Jr., E., Horton, E.S., Bray, G.A., Glennon, J.A., and Salans, L.B. 1973. Endocrine and metabolic effects of experimental obesity in man. Recent Prog. Horm. Res. 29: 457-496.

Smith, S.R., Bai, F., Charbonneau, C., Janderova, L., and Argyropoulos, G. 2003. A promoter genotype and oxidative stress potentially link resistin to human insulin resistance. Diabetes 52: 1611-1618.

Spiegelman, B.M. 1998. PPAR- $\gamma$ : Adipogenic regulator and thiazolidinedione receptor. Diabetes 47: 507-514.

St-Pierre, J., Lin, J., Krauss, S., Tarr, P.T., Yang, R., Newgard, C.B., and Spiegelman, B.M. 2003. Bioenergetic analysis of peroxisome proliferator-activated receptor $\gamma$ coactivators $1 \alpha$ and $1 \beta$ (PGC- $1 \alpha$ and PGC-1 $\beta$ ) in muscle cells. J. Biol. Chem. 278: $26597-26603$.

Stephens, J.M., Lee, J., and Pilch, P.F. 1997. Tumor necrosis factor- $\alpha$-induced insulin resistance in $3 \mathrm{~T} 3-\mathrm{L} 1$ adipocytes is accompanied by a loss of insulin receptor substrate- 1 and GLUT4 expression without a loss of insulin receptor-mediated signal transduction. J. Biol. Chem. 272: 971-976.

Steppan, C.M., Bailey, S.T., Bhat, S., Brown, E.J., Banerjee, R.R., Wright, C.M., Patel, H.R., Ahima, R.S., and Lazar, M.A. 2001. The hormone resistin links obesity to diabetes. Nature 409: $307-312$.

Steppan, C.M., Wang, J., Whiteman, E.L., Birnbaum, M.J., and Lazar, M.A. 2005. Activation of SOCS-3 by resistin. Mol. Cell. Biol. 25: 1569-1575.

Stith, R.D. and Luo, J. 1994. Endocrine and carbohydrate responses to interleukin-6 in vivo. Circ. Shock 44: 210-215.

Suganami, T., Tanimoto-Koyama, K., Nishida, J., Itoh, M., Yuan, X., Mizuarai, S., Kotani, H., Yamaoka, S., Miyake, K., Aoe, S., et al. 2007. Role of the Toll-like receptor 4/NF-кB pathway in saturated fatty acid-induced inflammatory changes in the interaction between adipocytes and macrophages. Arterioscler. Thromb. Vasc. Biol. 27: 84-91.

Suwazono, Y., Sakata, K., Okubo, Y., Harada, H., Oishi, M., Kobayashi, E., Uetani, M., Kido, T., and Nogawa, K. 2006. Long-term longitudinal study on the relationship between alternating shift work and the onset of diabetes mellitus in male Japanese workers. J. Occup. Environ. Med. 48: 455-461.

Takashima, N., Tomoike, H., and Iwai, N. 2006. Retinol-binding protein 4 and insulin resistance. N. Engl. J. Med. 355: 1392; author reply 1394-1395.

Tobiume, K., Matsuzawa, A., Takahashi, T., Nishitoh, H., Morita, K., Takeda, K., Minowa, O., Miyazono, K., Noda, T., and Ichijo, H. 2001. ASK1 is required for sustained activations of JNK/p38 MAP kinases and apoptosis. EMBO Rep. 2: 222-228.

Tomas, E., Tsao, T.S., Saha, A.K., Murrey, H.E., Zhang Cc, C., Itani, S.I., Lodish, H.F., and Ruderman, N.B. 2002. Enhanced muscle fat oxidation and glucose transport by ACRP30 globular domain: Acetyl-CoA carboxylase inhibition and AMP-activated protein kinase activation. Proc. Natl. Acad. Sci. 99: 16309-16313.

Tontonoz, P., Hu, E., Graves, R.A., Budavari, A.I., and Spiegelman, B.M. 1994. mPPAR $\gamma 2$ : Tissue-specific regulator of an adipocyte enhancer. Genes \& Dev. 8: 1224-1234.

Tsigos, C., Papanicolaou, D.A., Kyrou, I., Defensor, R., Mitsia- 
dis, C.S., and Chrousos, G.P. 1997. Dose-dependent effects of recombinant human interleukin-6 on glucose regulation. $J$. Clin. Endocrinol. Metab. 82: 4167-4170.

Turek, F.W., Joshu, C., Kohsaka, A., Lin, E., Ivanova, G., McDearmon, E., Laposky, A., Losee-Olson, S., Easton, A., Jensen, D.R., et al. 2005. Obesity and metabolic syndrome in circadian Clock mutant mice. Science 308: 1043-1045.

Ueki, K., Kondo, T., and Kahn, C.R. 2004a. Suppressor of cytokine signaling 1 (SOCS-1) and SOCS-3 cause insulin resistance through inhibition of tyrosine phosphorylation of insulin receptor substrate proteins by discrete mechanisms. Mol. Cell. Biol. 24: 5434-5446.

Ueki, K., Kondo, T., Tseng, Y.H., and Kahn, C.R. 2004b. Central role of suppressors of cytokine signaling proteins in hepatic steatosis, insulin resistance, and the metabolic syndrome in the mouse. Proc. Natl. Acad. Sci. 101: 10422-10427.

Unger, R.H. and Orci, L. 2000. Lipotoxic diseases of nonadipose tissues in obesity. Int. J. Obes. Relat. Metab. Disord. 24 (Suppl. 4): S28-S32.

Uysal, K.T., Wiesbrock, S.M., Marino, M.W., and Hotamisligil, G.S. 1997. Protection from obesity-induced insulin resistance in mice lacking TNF- $\alpha$ function. Nature 389: 610-614.

Vidal-Puig, A. and O'Rahilly, S. 2001. Resistin: A new link between obesity and insulin resistance? Clin. Endocrinol. (Oxf.) 55: 437-438.

Vozarova, B., Weyer, C., Hanson, K., Tataranni, P.A., Bogardus, C., and Pratley, R.E. 2001. Circulating interleukin-6 in relation to adiposity, insulin action, and insulin secretion. Obes. Res. 9: 414-417.

Wallenius, V., Wallenius, K., Ahren, B., Rudling, M., Carlsten, H., Dickson, S.L., Ohlsson, C., and Jansson, J.O. 2002. Interleukin-6-deficient mice develop mature-onset obesity. Nat. Med. 8: 75-79.

Wang, H., Chu, W.S., Hemphill, C., and Elbein, S.C. 2002. Human resistin gene: Molecular scanning and evaluation of association with insulin sensitivity and type 2 diabetes in Caucasians. J. Clin. Endocrinol. Metab. 87: 2520-2524.

Weisberg, S.P., McCann, D., Desai, M., Rosenbaum, M., Leibel, R.L., and Ferrante Jr., A.W. 2003. Obesity is associated with macrophage accumulation in adipose tissue. J. Clin. Invest. 112: $1796-1808$.

Weisberg, S.P., Hunter, D., Huber, R., Lemieux, J., Slaymaker, S., Vaddi, K., Charo, I., Leibel, R.L., and Ferrante Jr., A.W. 2006. CCR 2 modulates inflammatory and metabolic effects of high-fat feeding. J. Clin. Invest. 116: 115-124.

Wellen, K.E. and Hotamisligil, G.S. 2005. Inflammation, stress, and diabetes. J. Clin. Invest. 115: 1111-1119.

Wojtczak, L. and Schonfeld, P. 1993. Effect of fatty acids on energy coupling processes in mitochondria. Biochim. Biophys. Acta 1183: 41-57.

Wu, Z., Puigserver, P., Andersson, U., Zhang, C., Adelmant, G., Mootha, V., Troy, A., Cinti, S., Lowell, B., Scarpulla, R.C., et al. 1999. Mechanisms controlling mitochondrial biogenesis and respiration through the thermogenic coactivator PGC-1. Cell 98: 115-124.

Xu, H., Barnes, G.T., Yang, Q., Tan, G., Yang, D., Chou, C.J., Sole, J., Nichols, A., Ross, J.S., Tartaglia, L.A., et al. 2003. Chronic inflammation in fat plays a crucial role in the development of obesity-related insulin resistance. J. Clin. Invest. 112: 1821-1830.

Yamagishi, S.I., Edelstein, D., Du, X.L., Kaneda, Y., Guzman, M., and Brownlee, M. 2001. Leptin induces mitochondrial superoxide production and monocyte chemoattractant protein-1 expression in aortic endothelial cells by increasing fatty acid oxidation via protein kinase A. J. Biol. Chem. 276: 25096-25100.
Yamauchi, T., Kamon, J., Minokoshi, Y., Ito, Y., Waki, H., Uchida, S., Yamashita, S., Noda, M., Kita, S., Ueki, K., et al. 2002. Adiponectin stimulates glucose utilization and fattyacid oxidation by activating AMP-activated protein kinase. Nat. Med. 8: 1288-1295.

Yang, Q., Graham, T.E., Mody, N., Preitner, F., Peroni, O.D., Zabolotny, J.M., Kotani, K., Quadro, L., and Kahn, B.B. 2005. Serum retinol binding protein 4 contributes to insulin resistance in obesity and type 2 diabetes. Nature 436: 356-362.

Yin, M.J., Yamamoto, Y., and Gaynor, R.B. 1998. The anti-inflammatory agents aspirin and salicylate inhibit the activity of IкB kinase- $\beta$. Nature 396: 77-80.

Yki-Jarvinen, H. 2004. Thiazolidinediones. N. Engl. J. Med. 351: 1106-1118.

Yuan, M., Konstantopoulos, N., Lee, J., Hansen, L., Li, Z.W., Karin, M., and Shoelson, S.E. 2001. Reversal of obesity- and diet-induced insulin resistance with salicylates or targeted disruption of $I k k \beta$. Science 293: 1673-1677.

Zhang, Y., Proenca, R., Maffei, M., Barone, M., Leopold, L., and Friedman, J.M. 1994. Positional cloning of the mouse obese gene and its human homologue. Nature 372: 425-432.

Zimmet, P., Alberti, K.G., and Shaw, J. 2001. Global and societal implications of the diabetes epidemic. Nature 414: 782787.

Zinman, B., Hanley, A.J., Harris, S.B., Kwan, J., and Fantus, I.G. 1999. Circulating tumor necrosis factor- $\alpha$ concentrations in a native Canadian population with high rates of type 2 diabetes mellitus. J. Clin. Endocrinol. Metab. 84: 272-278. 


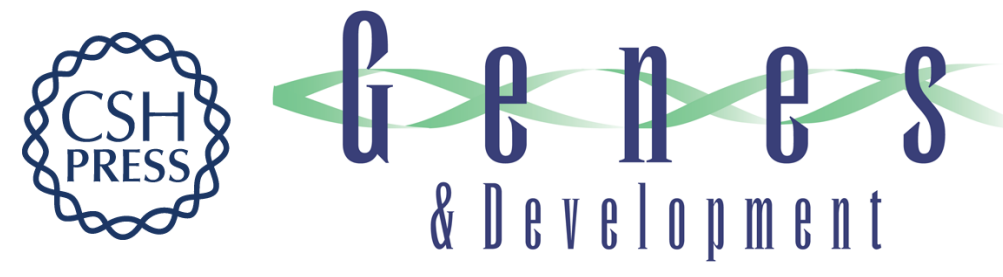

\section{Mechanisms of obesity-associated insulin resistance: many choices on the menu}

Mohammed Qatanani and Mitchell A. Lazar

Genes Dev. 2007, 21:

Access the most recent version at doi:10.1101/gad.1550907

References This article cites 193 articles, 65 of which can be accessed free at: http://genesdev.cshlp.org/content/21/12/1443.full.html\#ref-list-1

License

Email Alerting

Receive free email alerts when new articles cite this article - sign up in the box at the top Service right corner of the article or click here.

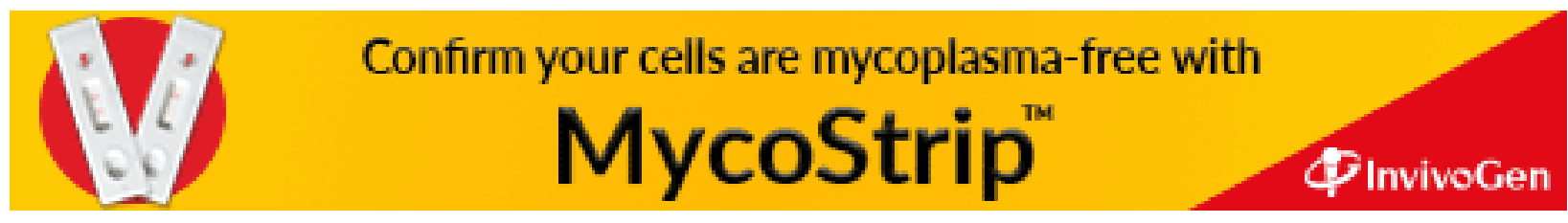

